\title{
Building a Positive Environment in Classrooms through Feedback and Praise
}

\author{
Asmaa Al-Ghamdi ${ }^{1}$ \\ ${ }^{1}$ English Language Institute, King Abdulaziz University, Jeddah, Kingdom of Saudi Arabia \\ Correspondence: Asmaa Al-Ghamdi, English Language Institute, King Abdulaziz University, Jeddah, Kingdom \\ of Saudi Arabia. E-mail: aalghamdi2855@stu.kau.edu.sa
}

Received: March 1, 2017 Accepted: May 20, 2017 Online Published: May 26, 2017

doi: 10.5539/elt.v10n6p37 URL: http://doi.org/10.5539/elt.v10n6p37

\begin{abstract}
There are many important pedagogical factors that need to be implemented in classrooms including language classrooms in order to build an incentive learning environment for the students. This paper sheds light on two of these main pedagogical factors which are feedback and praise. The main purpose of this paper is to alter negative perceptions among students about those estimation standards which are feedback and praise and to widen teachers' knowledge about providing them properly. In order to achieve the previous purposes, this paper explains different types of feedback and the impacts of feedback and praise on students' learning. It also provides teachers with tips and strategies about how to use feedback and praise effectively to reach the desired outcomes. Researchers have in the past expressed contradictory views about those estimation standards, thus; this paper takes into consideration positive and negative effects of them.
\end{abstract}

Keywords: factors, feedback, praise, estimation standards, strategies

\section{Introduction}

\subsection{Introduce the Problem}

Evaluating students can be considered a double-edged procedure in the educational domain. To some extent, it has been agreed that estimation standards such as teachers' feedback and praise on students' work in diverse learning fields can have both positive and negative outcomes on the learning process. Students, in particular, may be influenced by their instructors' assessments regarding their performed tasks. On one hand, they may become motivated, and therefore, be willing to complete extra valuable assignments (Elwell \& Tiberio, 1994; Glazer, 2007; Lipnevich \& Smith, 2008; Marzano, 2000; Sutherland, Wehby, \& Copeland, 2000; Sweigart, Landrum, \& Pennington, 2015). On the other hand, they may become careless and unwilling to do any further tasks because they are pleased with their current achievements (Cherne, 2008; Deci, Koestner, \& Ryan, 1999). In both cases, teachers need to know how their assessments can influence and impact students.

Some researchers have found that feedback and praise affect students positively and improve their learning (Lipnevich \& Smith, 2008). Others, in contrast, argue that feedback and praise lead to negative effects (Deci, Koestner, \& Ryan, 1999). These differences illustrate the basis for the current research paper. It attempts to investigate the influences of feedback and praise on students' learning. Also, it explains the need for feedback and praise to promote learning and to create a positive atmosphere in classrooms.

\subsection{Aims and Rationale}

There are several reasons that have encouraged the researcher to conduct this paper. First, it helps teachers to increase students' motivation towards learning by better understanding the effects of feedback and praise on students as well as help them learn how to provide these factors effectively. Also, this research benefits students by helping them to use feedback and praise provided by teachers to improve their learning and produce much better tasks.

In order to achieve all previously illustrated aims, this research has been organized to start with identifying different types of feedback and its effects on students' learning. After explaining strategies to provide effective feedback, praise and its influence on students are presented. The last point that will be explained is how to use praise effectively. 


\subsection{Significance of the Study}

The primary beneficiaries from this research are teachers. It will help them develop certain methods for giving more effective feedback and praise and to be aware of the impacts of these factors on students' learning. When proper methods of evaluation are used, with balanced schemes that meet learners' need; the fundamental purpose of education can be achieved. This research is also beneficial for students because the use of effective feedback and praise can enhance their learning process and motivate them to complete well-developed tasks. It will help them to alter negative perceptions about feedback provided by their teachers. In addition, teacher trainers who conduct training programs for teachers can benefit from this research as it will help them focus on incorporating discussions on the positive and negative impacts of feedback and praise on students' learning.

\section{Literature Review}

\subsection{Feedback}

Feedback is an information or a description provided by teachers which aims to improve students' performance. It allows students to assess themselves, to know their level in the process of learning and to help them "fill the gap between where they are in their learning and where they need to be" (Davies, 2007, p. 38).

It comes from someone who has a sufficient experience in the field and who cares so much about one's work to read it accurately and comment on it (Brookhart, 2008). This someone is the teacher who reads all students' work precisely and provides feedback to improve their future performances.

Feedback is the most significant tool in the educational system as Marzano, Waters, and McNulty (2005) identified the need to create a system that serves feedback as its essence for observing and evaluating students. Also, Hattie (2009) found that feedback is among the most important factors that influence students' learning process. He drew this conclusion after integrating over 800 meta-analysis and a huge number of studies.

\subsubsection{Types of Feedback}

Researchers have suggested different typologies and categories of feedback. Hattie and Timperley (2007) provided a model of feedback which consists of three kinds and these are: feed up, feedback and feed forward. First, feed up means to direct a person towards a goal. The teacher provides instructions for the students to help them to attain the desired goal. It is important to specify a goal from the beginning because if the goal is not allocated appropriately, students will face difficulties. Second, feedback is conveyed by the teacher to inform the students about how they did in a performed task. The third type is feed forward which means to direct the students where to go next. The teacher should guide the students towards the coming challenges after achieving previous goals. All these three kinds work together and incorporate to promote learning.

Hattie and Timperley (2007) developed another classification which categorized feedback into four levels. The first is the task level which provides information about how well a task was accomplished. It also informs a person about the neatness and the correctness or incorrectness of a work. Second, the process level identifies the process or the strategy used to perform a task. Third, the self-regulation level aims to develop the students' skills in self-evaluation and self- monitoring and to increase their confidence. It also improves students' abilities to have control over actions. Finally, the self- level is related to self rather than performance. It involves personal evaluations about learners' personalities. The process and self- regulation levels were considered the most effective in improving individuals but the self- level was considered the least effective.

Students are different in their learning and accordingly, they need different types of feedback. Beginners need corrective feedback that provides them with information about the correctness of their performance. Alternatively, professionals need process feedback. Intermediate students have acquired the basics but they need to be guided to form alternative strategies and to relate ideas together. Students who are highly competent need self- regulation feedback along with detailed descriptions because they are ready to expand their knowledge whenever possible (Banerjee, 2014).

Types of feedback have been categorized in several ways. First, regarding intentionality, there is intentional feedback that tells students general factors about their performance such as quality, accuracy and suitability. Unintentional feedback occurs naturally from interactions with others. In classrooms, it occurs in pair interactions, group work and unplanned situations (Bangert-Drowns, Kulik \& Morgan, 1991).

Intentional feedback has been classified according to the way in which the students receive it. Direct feedback is provided by a human being like a teacher or a classmate to a student during communication together. However, indirect feedback is conveyed to students via devices (Leontyev, 1981 as cited in Lipnevich \& Smith, 2008). Computer-provided feedback is an example of indirect feedback. 
Educational technology such as computers can give feedback to students regarding their completed tasks. Some researchers claimed that learners doubt the feedback provided by computers and find computers' responses as implausible and unreasonable (Lepper, Woolverton, Mumme, \& Gurtner, 1993). Others, in contrast, stated that some people deal with computers as intentional social actors (Nass, Moon \& Carney, 1999). Ferdig and Mishra (2004) found that some people punished these machines while others showed respect to them. Another study showed that some people deem them as expert fellows (Nass, Fogg \& Moon, 1996).

Direct and indirect feedback can be differentiated regarding quantity and information's type conveyed to students. Quantity represents the volume of provided information, starting from the first letter to an elaborated description about students' performance. Information's type has been classified into descriptive feedback and evaluative feedback. Descriptive feedback informs students about how they perform a particular task and gives a detailed explanation to overcome difficulties with the task and to improve future performances. However, evaluative feedback conveys information about the correctness of answers. It can be considered judgemental because it represents the number of correct items, e.g., grades or scores (Linn \& Miller, 2005).

\subsubsection{Effects of Feedback on Students' Learning}

One major factor that can affect students is their teachers' feedback. In some cases, it has been noticed that detailed and direct commentaries on learners' work play a significant role in making them more conscious, engaged, and committed to their tasks. Firstly, instructors' explanatory feedback can support students' awareness. Lipnevich and Smith (2008) study about the influence of feedback on undergraduate students' performance, showed that detailed feedback can be an effective way to motivate them. The study found that feedback which provides students with information about how to perform tasks they are assigned to correctly, or solutions on how to solve problems they face properly, can lead to a great improvement in the quality of their work. Proper feedback can encourage them to develop the knowledge and intellect they need to accomplish advanced assignments. Secondly, educators' feedback can help learners to recognize what they need to focus on if they have certain difficulties. Teachers can help students better engage within their tasks if they provide commentaries directly to them (Sutherland et al., 2000). Engaging within a task is a key element to success in the educational field since it helps students to concentrate on achieving their educational goals and to overcome their obstacles. Thirdly, immediate feedback may be an important factor in increasing students' commitment towards completing those tasks. As explained by Sweigart et al. (2015), visual performance feedback, through gestures or smile, can enhance learners' engagement in the classroom. This may in turn improve educational practice for both instructors and pupils. All of these outcomes make it clear that teachers' feedback is an effective factor in promoting students' learning.

However, some argue that instructors' feedback about their learners' accomplishments may lead to undesirable effects such as anxiety and disturbance in classrooms' atmosphere. First, teachers' feedback can hinder students' sense of pride and hope. Learners' feelings of self-importance and great expectation might be hindered due to the emergence of negative emotions like nervousness and sadness (Pekrun, Cusack, Murayama, Elliot, \&Thomas, 2014). This might occur if teachers do not diversify the type of commentaries they give to students. According to McMillan (2012), there are a number of teachers who do not clarify the aims of their feedback and the way to interpret them. Thus, students cannot improve as they are $t$ aware of their points of strength and weaknesses. In brief, these types of commentaries on learners' work can lead to negative outcomes that teachers need to be aware of.

\subsubsection{How to Provide Students with Effective Feedback}

There is an art to provide feedback and once it is conveyed improperly, students will receive it as criticism (Miser, 1999). Researchers provide numerous suggestions and ways for teachers to provide effective feedback. The most important way is to accept students' errors and they must be welcomed (Hattie \& Timperley, 2007).

Providing effective feedback is a skill that all teachers need to master in order to promote students' learning. Brookhart (2008) suggested different strategies for teachers to give useful feedback. First, regarding time, written feedback can be delayed for a short period of time to give teachers an opportunity to comprehend the written task deeply but it should not be delayed till losing its effectiveness. Second, feedback should provide only the most important points that belong to the desired goal. Third, there are three modes in which the teacher chooses the best that suit the message needs to be conveyed. Oral mode is the best when possible and it means face-to-face conversation between the teacher and the student. The second mode is the written feedback which is appropriate for students' written assignments. The third is the demonstration in which the student who faces difficulties is provided with steps on how to do something.

Turning now to explain what the content of feedback should offer to students as suggested by Brookhart (2008). 
First, a good content of feedback contains comments about the strength and weaknesses of the work itself and it is helpful to use a rubric to compare students' work with it. The use of rubrics helps the teacher to focus only on the work without giving any personal comments such as "good girl" or "smart girl". Personal comments should be avoided because they do not offer any help for improving students' learning. It may lead to a belief that intelligence is fixed and this can hinder students from making further effort to accomplish their goals (Dweck, 2007). Second, the good content is descriptive and constructive but not judgmental and it provides suggestions for development. The clarity of the words is another important aspect which means that the vocabulary used by the teacher can be understood. The fourth aspect is to identify errors without supplying correct answers. Finally, the words have to show respect for both student and the work.

\subsection{Praise}

As the term feedback has been defined differently, similarly, there are various definitions of praise provided in literature. Praise is a "favorable interpersonal feedback" (Baumeister, Hutton, \& Cairns, 1990, p. 131) or it means "to commend the worth of or to express approval or admiration" (Brophy, 1981, p. 5). It is provided after an accomplishment of a task or a desired behavior to express admiration (Dev, 1997; Dreikurs, Grunwald, \& Pepper, 1982).

\subsubsection{Effects of Praise on Students' Learning}

Praise has a clear influence on students in which it can motivate or demotivate them. In areas where praise can be a motivator for educational success, some researchers agree on the benefits of complimenting students' tasks (Elwell \& Tiberio, 1994; Glazer, 2007). Praise is a powerful tool for improving academic performance and it may give students the proper strategies to apply in order to perform successful tasks. A study by Matheson and Shriver (2005) showed that praising students' achievements in addition to efficient guidelines may possibly be a sufficient technique in guiding them to achieve a higher standard of work quality as well as forming positive interpersonal relationships with teachers. Secondly, praise can promote a warm and lovely mood in classrooms. It is very important for educators and learners to have a positive relationship and this can be built through the use of effective praise as a major strategy to make classrooms more efficient and inspiring places to learn (Conroy, Sutherland, Snyder, \& AlHendawi, 2009; Dowd \& Tierney, 2005; Frenzel, Goetz, Lüdtke, Pekrun, \& Sutton, 2009; Hensley, Powell, Lamke, \& Hartman, 2011). Generally, praise can be a valid approach to encourage further students' task achievement.

On the contrary, other researchers claim that praising learners may have adverse outcomes. Praise can lead to a variety of negative attitudes in learning such as the deficiency in hard work, less creativity, and lower intrinsic motivation. As Lipnevich and Smith (2008) explained, students who have already received a lot of praise might not be eager to put forth any extra effort and thus, they may become satisfied with what they have previously accomplished. These students might not work to improve their current status. The other negative result of complimenting pupils is that it may decrease creativity in the academic work. Students might feel the need to repeat the same type of work, which they deem as preferable (Cherne, 2008). This may happen as a result of a high praise. It is also possible that students' intrinsic motivation can be influenced by praising. Deci et al. (1999) indicated that praising in the instructive process can make students focus more on their interest in receiving praise rather than on the tasks they assigned to do. They advised teachers to make a balanced strategy of how and when to praise their students' work.

\subsubsection{How to Use Praise Effectively}

There are teachers who do not use praise effectively or use it rarely (Beaman \& Wheldall, 2000). Here are different features of what effective praise should contain. First, praise should consist of expressions that are related to a specific task or behavior because students need to know which task or behavior is being complimented (Sutherland et al., 2000). "Great job! You applied past simple appropriately in your first quiz" or " you were an attentive listener in today's class" are examples of effective praise. Second, praise should be provided immediately after a performed task or behavior (Willingham, 2005). Third, some students try to elicit praise from teachers but in order for praise to be effective, it has to be initiated by the teacher (Hitz, \& Driscoll, 1988). Fourth, praise has to be free from pretense or exaggeration and it has to be delivered with a positive voice. Praise's statements are different according to the recipients of praise. That is, undergraduate students should receive different statements from those provided to teenagers (Conroy et al., 2009). Fifth, it is important to provide many praises while a student is acquiring a skill but after this skill has been acquired, the amount of praise should be decreased. Then, the teacher moves to praise another progress until it has been accomplished accurately (Conroy et al., 2009). Finally, praise should be provided without making any comparisons with other colleagues' work in the classroom. This can create a feeling of competition or jealous between classmates. Apart 
from that, the teacher can compare students' work with previous ones to show the improvement of a particular aspect.

It is important for teachers to know how to provide effective praise because this can lead to a great development in the future. Praise is a strong reinforcer that can foster students' motivation towards learning, if it is provided effectively (Brophy, 1981; Hitz, \& Driscoll, 1988).

\section{Conclusion}

To sum up, effective feedback and praise are significant teaching tools that need to be implemented by teachers in order to promote students' learning and foster a positive relationship between the teacher and students. This paper has classified various types of feedback and it has provided different definitions of feedback and praise. Also, the effects of them on students' learning have been illustrated along with useful strategies for providing effective feedback and praise. Most students can reach the same level of achievement whenever proper feedback and praise are provided.

\section{Recommendations for Further Studies}

This paper has discussed many areas in need of further investigation. First, it is recommended that an assessment of the impacts of other estimation standards such as grades, is taken into consideration. Second, the effects of feedback and praise on students' emotions would be a fruitful area for further work. Finally, empirical studies need to be conducted to explore whether students of different ages would understand feedback or praise messages differently.

\section{References}

Banerjee, A. (2014). Improving student's learning with correct feedback: A model proposed for classroom utility. International Journal of Education and Psychological Research, 3(4), 36-40.

Bangert-Drowns, R. L., Kulik, J. A., \& Morgan, M. T. (1991). The instructional effect of feedback in test-like events. Review of Educational Research, 61, 213-238. https://doi.org/10.3102/00346543061002213

Baumeister, R. F., Hutton, D. G., \& Cairns, K. J. (1990). Negative effects of praise on skilled performance. Basic and Applied Social Psychology, 11, 131-148. https://doi.org/10.1207/s15324834basp1102_2

Beaman, R., \& Wheldall, K. (2000). Teachers' use of approval and disapproval in the classroom. Educational Psychology, 20, 431-446. https://doi.org/10.1080/713663753

Brookhart, S. M. (2008). How to give effective feedback to your students. Retrieved from http://www.ascd.org/publications/books/108019/chapters/Types-of-Feedback-and-Their-Purposes.aspx

Brophy, J. (1981). Teacher praise: A functional analysis. Review of Educational Research, 51, 5-32. https://doi.org/10.3102/00346543051001005

Cherne, J. (2008). Effects of Praise on Student Behavior in the Classroom. Unpublished doctoral dissertation, University of Minnesota, Twin Cities, MN.

Conroy, M. A., Sutherland, K. S., Snyder, A. \& AlHendawi, M. (2009). Creating a Positive Classroom Atmosphere: Teachers' Use of Effective Praise and Feedback. Beyond Behavior, 18(2), 18-26.

Davies, A. (2007). Involving students in the classroom assessment process. In D. Reeves (Ed.), Ahead of the curve: the power of assessment to transform teaching and learning (pp. 31-38). Bloomington, IN: Solution Tree Press.

Deci, E. L., Koestner, R., \& Ryan, R. M. (1999). A meta-analytic review of experiments examining the effects of extrinsic rewards on intrinsic motivation. Psychological Bulletin, 125, 627-668. https://doi.org/10.1037/0033-2909.125.6.627

Dev, P. C. (1997). Intrinsic motivation and academic achievement: What does their relationship imply for the classroom teacher. Remedial and Special Education, 18, 12-19. https://doi.org/10.1177/074193259701800104

Dowd, T. \& Tierney, J. (2005). Teaching social skills to youth: A step-by-step guide to 182 basic to complex skills plus helpful teaching techniques (2nd ed.). Boys Town, NE: Boys Town Press.

Dreikurs, R., Grunwald, B. B., \& Pepper, F. C. (1982). Maintaining sanity in the classroom: Classroom management techniques (2nd ed.). New York, NY: Harper and Row.

Dweck, C. S. (2007). The perils and promises of praise. Educational Leadership, 65(2), 34-39. 
Elwell, W. C., \& Tiberio, J. (1994). Teacher praise. Journal of Instructional Psychology, 21, 322-328.

Ferdig, R. E., \& Mishra, P. (2004). Emotional responses to computers: Experiences in unfairness, anger and spite. Journal of Educational Multimedia and Hypertext, 13(2), 143-161.

Frenzel, A. C., Goetz, T., Lüdtke, O. Pekrun, R., \& Sutton, R. E. (2009). Emotional transmission in the classroom: Exploring the relationship between teacher and student enjoyment. Journal of Educational Psychology, 101, 705-716. https://doi.org/10.1037/a0014695

Glazer, S. M. (2007). Spontaneous praise. Teaching PreK-8, 37(7), 62-65.

Hattie, J., \& Timperley, H. (2007). The power of feedback. Review of Educational Research, 77(1), 81-113. https://doi.org/10.3102/003465430298487

Hattie, J. (2009). Visible learning: A synthesis of over 800 meta-analyses relating to achievement. New York, NY: Routledge.

Hensley, M., Powell, W., Lamke, S. \& Hartman, M. (2011). Well-managed schools: Strategies to create a productive and cooperative social climate in your learning community. Omaha, NE: New Boys Press.

Hitz, R., \& Driscoll, A. (1988). Praise or encouragement? New insights into praise: Implication for early childhood teachers. Young Children, 43(5), 6-13.

Lepper, M. R., Woolverton, M., Mumme, D. L., \& Gurtner, J. (1993). Motivational techniques of expert human tutors: Lessons for the design of computer-based tutors. In S. P. Lajoie, \& S. J. Derry (Eds.), Computers as cognitive tools (pp. 75-105). Hillsdale, NJ: Erlbaum.

Linn, R. L., \& Miller, M. D. (2005). Measurement and assessment in teaching (9th ed.). Upper Saddle River, NJ: Pearson Prentice Hall.

Lipnevich, A. A., \& Smith, J. K. (2008). Response to assessment feedback: The effects of grades, praise, and source of information. ETS Research Report Series, 2008(1), i-57. https://doi.org/10.1002/j.2333-8504.2008.tb02116.x

Marzano, R. (2000). Transforming classroom grading. Alexandria, VA: Association for supervision and Curriculum and Development.

Marzano, R. J., Waters, J. T., \& McNulty, B. A. (2005). School leadership that works: From research to results. Retrieved

from http://www.ascd.org/publications/books/105125/chapters/In-Search-of-School-Leadership.aspx

Matheson, A. S., \& Shriver, M. D. (2005). Training teachers to give effective commands: effects on student compliance and academic behaviors. School Psychology, 34(2), 202-219.

McMillan, J. (2012). SAGE Handbook of Research on Classroom Assessment. SAGE Publications. Thousand Oaks, CA: Sage Publications.

Miser, W.F. (1999). The Family Physician as Teacher - Giving Effective Feedback. The Ohio Family Physician, $51(8), 12-13$.

Nass, C., Fogg, B. J., \& Moon, Y. (1996). Can computers be teammates? International Journal of Human-Computer Studies, 45(6), 669-678. https://doi.org/10.1006/ijhc.1996.0073

Nass, C., Moon, Y., \& Carney, P. (1999). Are respondents polite to computers? Social desirability and direct responses to computers. Journal of Applied Social Psychology, 29(5), 1093-1110. https://doi.org/10.1111/j.1559-1816.1999.tb00142.x

Pekrun, R., Cusack, A., Murayama, K., Elliot, A., Thomas, K. (2014). The power of anticipated feedback: Effects on students' achievement goals and achievement emotions. Learning and Instruction, 29, 115-124. https://doi.org/10.1016/j.learninstruc.2013.09.002

Sutherland, K. S., Wehby, J. H., \& Copeland, S. R. (2000). Effects of varying rates of behavior-specific praise on the on-task behavior of students with emotional and behavioral disorders. Journal of Emotional and Behavioral Disorders, 8, 2-8. https://doi.org/10.1177/106342660000800101

Sweigart, C., Landrum, T., \& Pennington, R. (2015). The effect of real-time visual performance feedback on teacher feedback: A preliminary investigation. Education \& Treatment of Children, 38(4), 429-450. https://doi.org/10.1353/etc.2015.0024

Willingham, D. L. (2005). Ask the cognitive scientist: How praise can motivate—or stifle. American Educator, 
29, 23-27.

\section{Copyrights}

Copyright for this article is retained by the author(s), with first publication rights granted to the journal.

This is an open-access article distributed under the terms and conditions of the Creative Commons Attribution license (http://creativecommons.org/licenses/by/4.0/). 